\begin{tabular}{lcccr} 
T H E & A R C H I V E & O F & M E C H A N I C A L & E N G I N E E R I N G \\
\hline VOL. LVIII & 2011 & Number 1
\end{tabular}

10.2478/v10180-011-0004-8

Key words: axial compressor stage, stall inception, rotating stall, short and long length scale disturbances, Fourier analysis, wavelet analysis

\title{
APPLICATION OF THE WAVELET TRANSFORM OF PRESSURE SIGNALS FOR DETECTING AND ANALYZING ROTATING STALL INCEPTION IN AXIAL FLOW LOW SPEED COMPRESSOR STAGE
}

The paper presents a research program carried out to improve understanding of the fluid dynamics mechanisms that lead to rotating stall in the axial flow low speed compressor stage. The stalling behavior of this compressor stage was studied by measuring unsteady casing pressure by means of a circumferentially and axially spaced array of high frequency pressure transducers. Another probe used was a disc static pressure probe, with the pressure transducer, for in-flow and out-flow measurements along the blade span. It was expected that understanding of the fluid dynamics will facilitate at least two important tasks. The first was to accurately predict of when and how a particular compressor would stall. The second was to control, delay, or eventually suppress the rotating stall and surge. In consequence, one could extend the useful operating range of the axial compressor. Another motivation for the research was to compare the results from the three applied analysis techniques by using a single stall inception event. The first one was a simple visual inspection of the traces, which brought about a very satisfactory effect. The second one was application of spatial Fourier decomposition to the analysis of stall inception data, and the third method of analysis consisted in application of wavelet filtering in order to better understand the physical mechanisms which lead to rotating stall. It was shown that each of these techniques would provide different information about compressor stall behavior, and each method had unique advantages and limitations.

* Silesian University of Technology, 44-100 Gliwice, Konarskiego 18 Str., Poland; e-mail: marcin.ziach@polsl.pl

** Silesian University of Technology, 44-100 Gliwice, Konarskiego 18 Str., Poland; e-mail: miroslaw.majkut@polsl.pl

*** Silesian University of Technology, 44-100 Gliwice, Konarskiego 18 Str., Poland; e-mail: andrzej.witkowski @polsl.pl 


\section{Introduction}

The onset of rotating stall in an axial compressor involves interaction of the flow in individual blade passages with the overall dynamics of the compression systems in which the machine operates. So, it is generally accepted that two types of stall inception occur [1-7]. One of them is the long wavelength stall inception (modal) in which a long length-scale disturbance (LLSD) growth in amplitude gradually under an unstable condition of the whole compression system. Another one is the short wavelength stall inception (spike-type inception) in which a short length-scale disturbance (SLSD) grows in size rapidly under a condition of high rotor incidence angles. In general, the spiky short length-scale disturbance (SLSD) appears locally and can be captured near the rotor leading edge, while the long length disturbance (LLSD) is detected over a wide range of axial directions. The purpose of stall inception data analysis is to identify and separate these effects. Experimental investigations of axial compressor pre-stall and stall inception generally involve circumferential arrays of sensors at one or more axial locations in the flow passage. A typical setup used by many investigators $[1,2,5,9,13]$ involves eighth or sixteenth hot-wire probes or static pressure transducers mounted circumferentially through the casing upstream of the rotor. Velocity or pressure data are then recorded with high temporal resolution, while the compressor is throttled toward stall. The circumferential distribution of the sensors allows for tracking of rotating features in the flow. Therefore, in this study sixteen pressure transducers were mounted on the casing wall $4.1 \mathrm{~mm}$ upstream of the rotor leading edge at intervals of $22.5 \mathrm{deg}$ in the circumferential direction in order to examine both disturbances in the stalling process. The occurrence of the spiky SLSDs could be seen clearly in the pressure trace when the signal component of blade passing frequency was filtered out by a low-pass filter. However, the characteristic of LLSD with a small amplitude could not be observed when the number of SLSDs was increased. Although the LLSD can be observed by taking the discrete Fourier Transform in the space about the circumference of the compressor, this technique cannot be used for SLSD [5]. On the other hand, a wavelet transform is useful for looking into a transient event of disturbances with different scale, and has recently been used for investigating the compressor stalling process $[1,5,7]$. Therefore, in this study, in order to look into the behavior of SLSD and LLSD simultaneously, the sixteenth pressure traces are analyzed with the following wavelet pressure transforms. Most of the experimental data, available in the public domain, focuses on unsteady pressure measurements along the axis or circumference of the compressor shroud. Only a few references [8] could be found concerning measurements along the blade span before and behind the 
rotor during the rotating stall regime. Two types of high-response pressure probes were used for these investigations. The first probe was a wall plug for wall static pressure measurements in the axial and circumferential directions. Next, newly designed and in-house built disc pressure probe with miniature transducer was used to measure static pressure distributions along the blade height in front of and behind the rotor.

In this study, we conducted measurement and analysis of the unsteady pressure field on the casing wall in the compressor annulus and along rotor blade passage, and investigated the variation of static pressure in the span direction upstream and downstream of the rotor in order to understand the flow characteristic and the structure of the stall cell under rotating stall. Simple visual inspection of the traces and different signal processing methods based on Fourier Transform can be used for the analysis of the pressure signals: the Fast Fourier Transform (FFT) method $[1,7,9,10,11,17]$ and the Wavelet Transform method $[1,5]$.

\section{Experimental facility and instrumentation}

Experimental investigations were carried out in the axial flow low speed compressor stage connected to the suction side of the measuring collector described by Witkowski et al. [15-17]. A cross section of the facility is shown in Fig. 1.

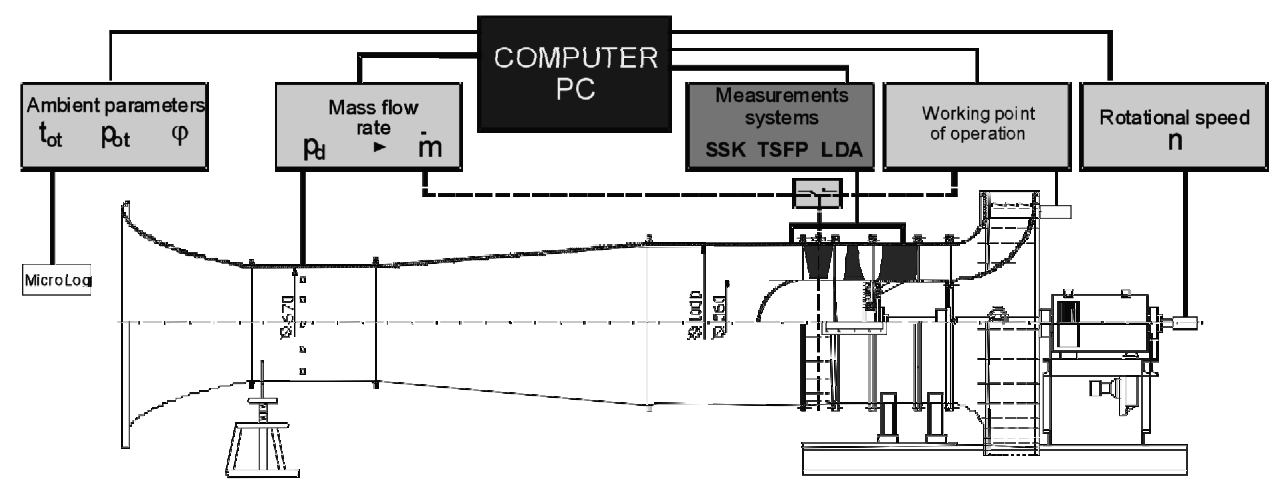

Fig. 1. Test setup

This stage consists of an inlet guide vane followed by a rotor with a hub to tip annulus wall diameter ratio of 0.56 , with outer diameter of 1.0 $\mathrm{m}$, with 16 cambered and twisted blades of British C-4 section designed for free vortex operation, followed by a 13-vane stator row and the outflow curvilinear diffuser with throttling blades.

Periodic multisampling and averaging technique was applied with a high response pressure sensor to obtain phase-locked pressure distribution and 


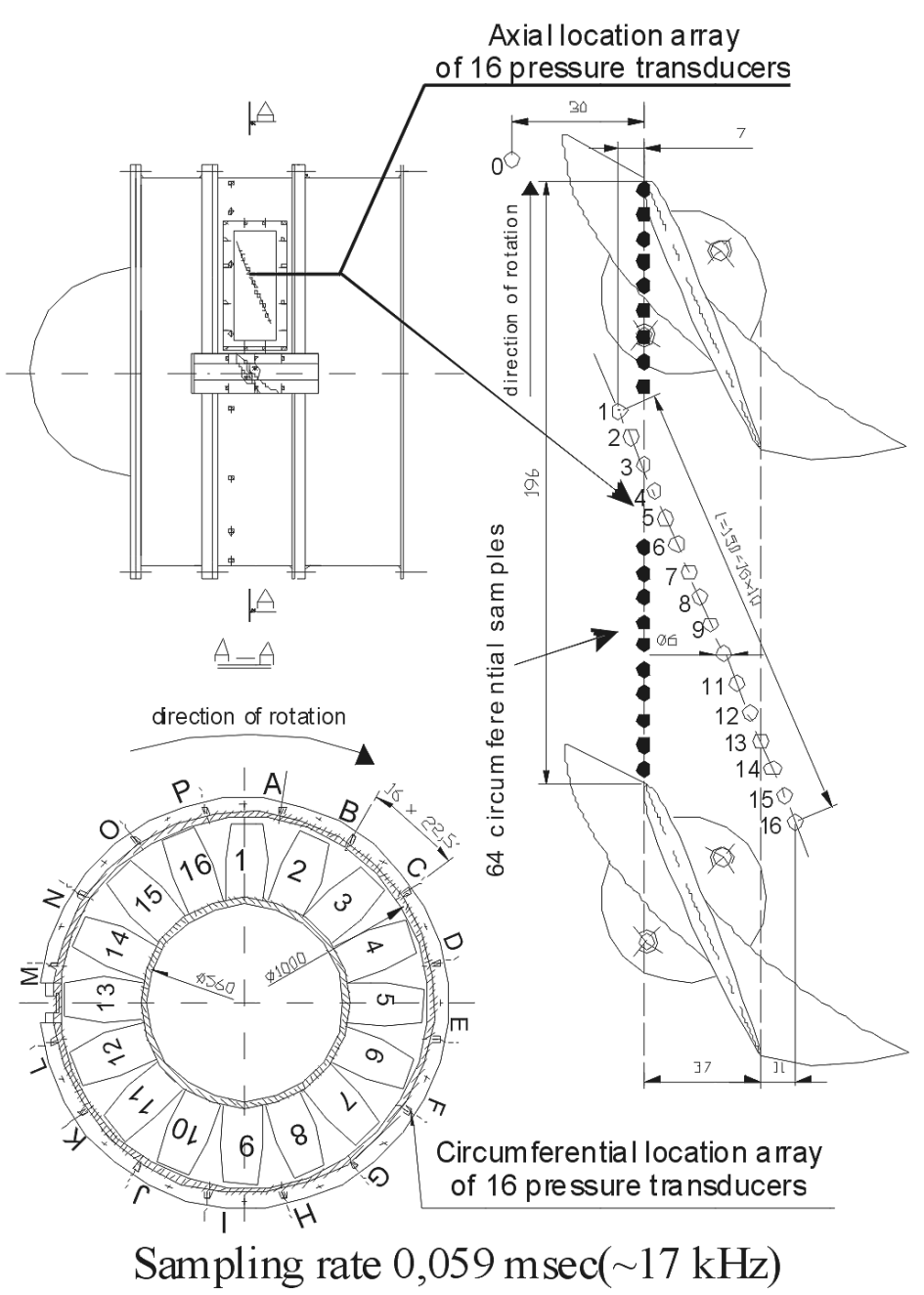

Fig. 2. Location of circumferential and rotor blade passage pressure transducer

its fluctuation on the casing wall. Recent advances in sensor technology have allowed for recording a greater amount of pressure signal data. 32 high-sensitivity pressure transducers with high natural frequency $(150 \mathrm{kHz})$ were used in the experiments for measuring the unsteady pressure field on the rotor-casing wall. The circumferential location array of 16th pressure transducers A through P, 1.3 axial chord of the rotor ahead of the rotor leading edge are depicted in Figure 2. For detailed pressure-field survey, another 16-th pressure transducers were placed along their rotor blade passage on the casing wall, as shown in Fig. 2. Newly designed, in-house built disc pressure probe with miniature transducer was additionally used in this study in order 


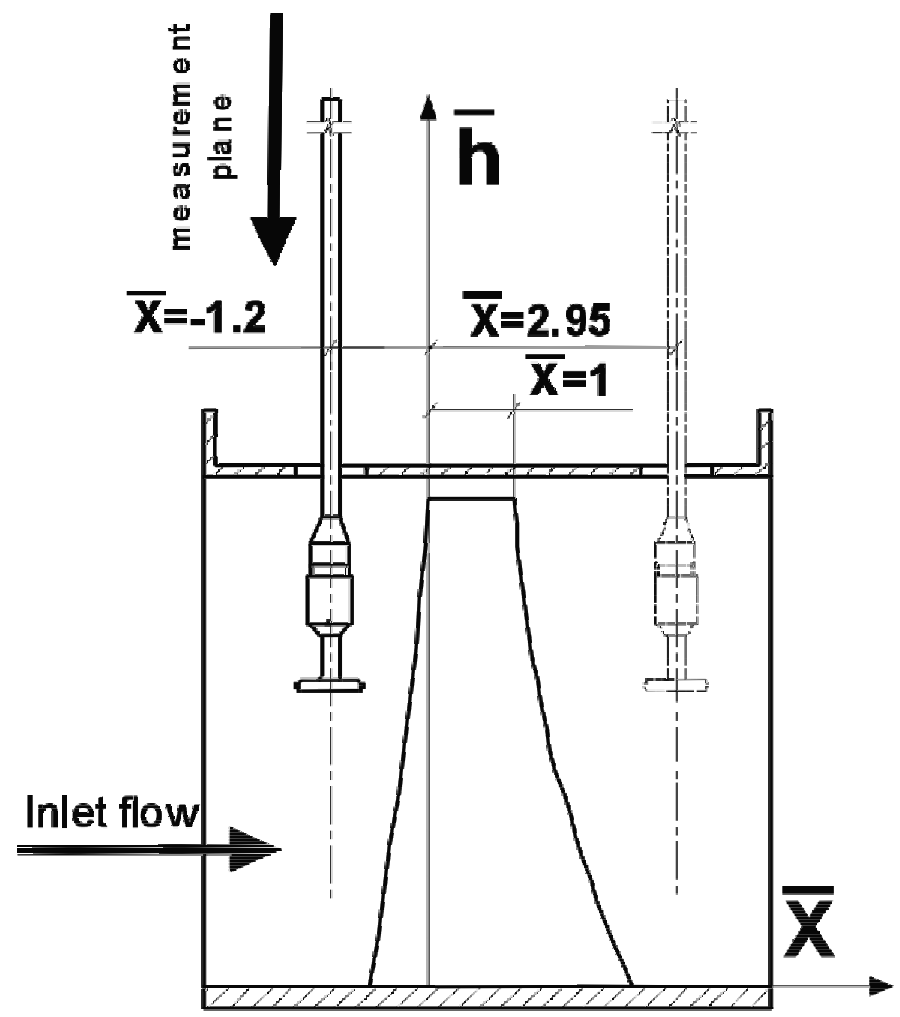

Fig. 3. View of disc static pressure probe

to measure static pressure distributions along the blade height upstream and downstream of the rotor (Fig. 3).

\section{Experimental results and discussion}

\subsection{Performance characteristic curve}

The total pressure rise was measured to determine the performance of the impeller. Figure 4 shows the performance characteristics of the tested impeller. As the flow rate decreases, the pressure coefficient $\psi$ increases and then drops at a flow rate of approx. $\phi=0.345$. The rotating stall occurs at a flow rate of approx. $\phi=0.324$ and the condition of the compressor impeller shifts to an unstable operating regime. The stall phenomenon was observed intermittently at the flow ranges of $\phi=0.37-0.251$. The characteristic was recorded by closing and opening the throttle and thus it exhibits a hysteresis in the stalled region. 


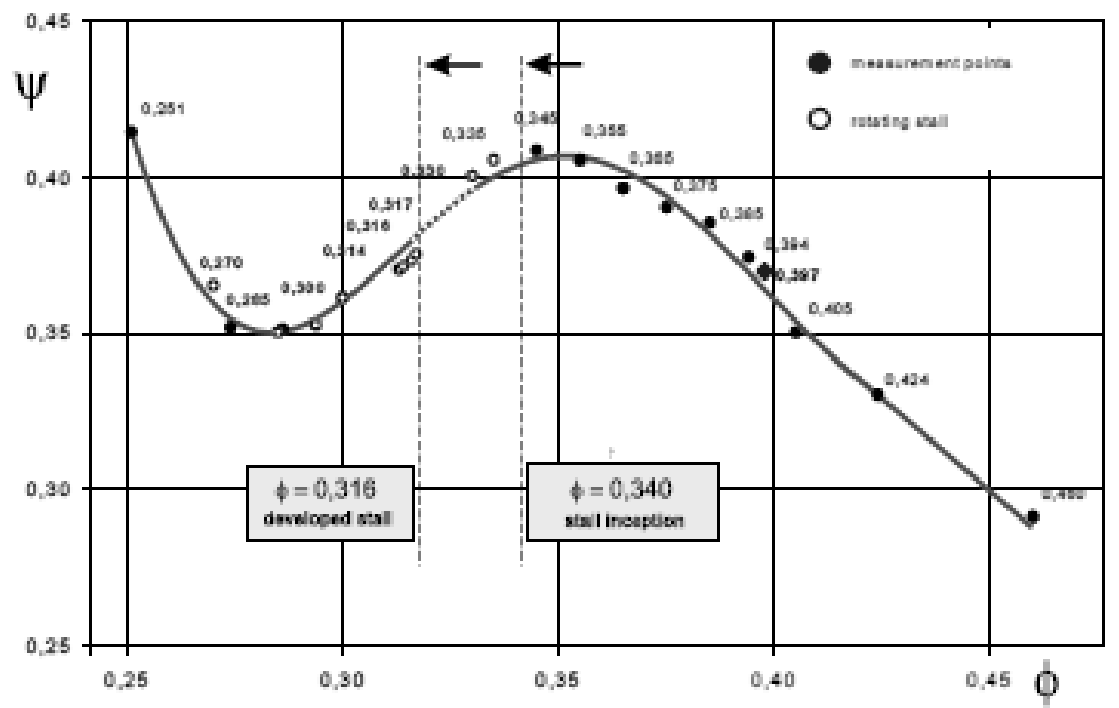

Fig. 4. Overall performance characteristic of the rotor

\subsection{Methods of stall inception analysis}

Several methods have been developed to analyze stall inception data obtained from circumferential and axial sensor arrays. Day [2] and many others (including the author's papers [16-17]) have applied simple visual inspection of the traces with good result. Kim et al [7] and Maertz et al [11] apply Fast Fourier Transform to the analysis of stall inception data. More recently, some investigators have applied wavelet filtering in an effort to better understand the physical mechanisms which lead to rotating stall $[1,5]$.

\subsubsection{Visual inspection}

Visual inspection of stall inception can provide meaningful, general information about stall inception behavior.

\section{Pressure fluctuations in circumferential direction}

To determine the number of stall cells, sixteen pressure sensors were placed around the circumference of the casing at the inlet of the rotor (Fig. 2). The accuracy of this characteristic will increase with the increasing number of sensors. Fig. 5 shows pressure fluctuations over the circumference of the tip of the rotor in the transverse cross section " 0 ", captured by five chosen pressure transducers A through I during the stabilized process of stall rotation. The angular distance between the two locations of sensors, A and I, is 
equal to $180^{\circ}$. The dashed lines in Fig. 5 connect points at which the signals have the same phases of the rotor blade (RB) and cells rotation (CR). The phase differences between the oscillations recorded by any pair of the sensors are equal to the differences between the sensor location angles on the rotor casing. The rotational period of the pressure field is equal to the period of pressure oscillation. From Fig. 5, we may also learn that the duration of the stall cell is equal to the time interval in which the blade rotates from measuring point A to point I. It confirms earlier observations [17] that the pressure fluctuations, which affects the flow at a flow rate of $\phi=0.314$, represents the oscillation of one stall cell and rotates at relatively low speed, of less than 41 percent of the rotor speed. It is denoted by the dashed line marked with (CR).

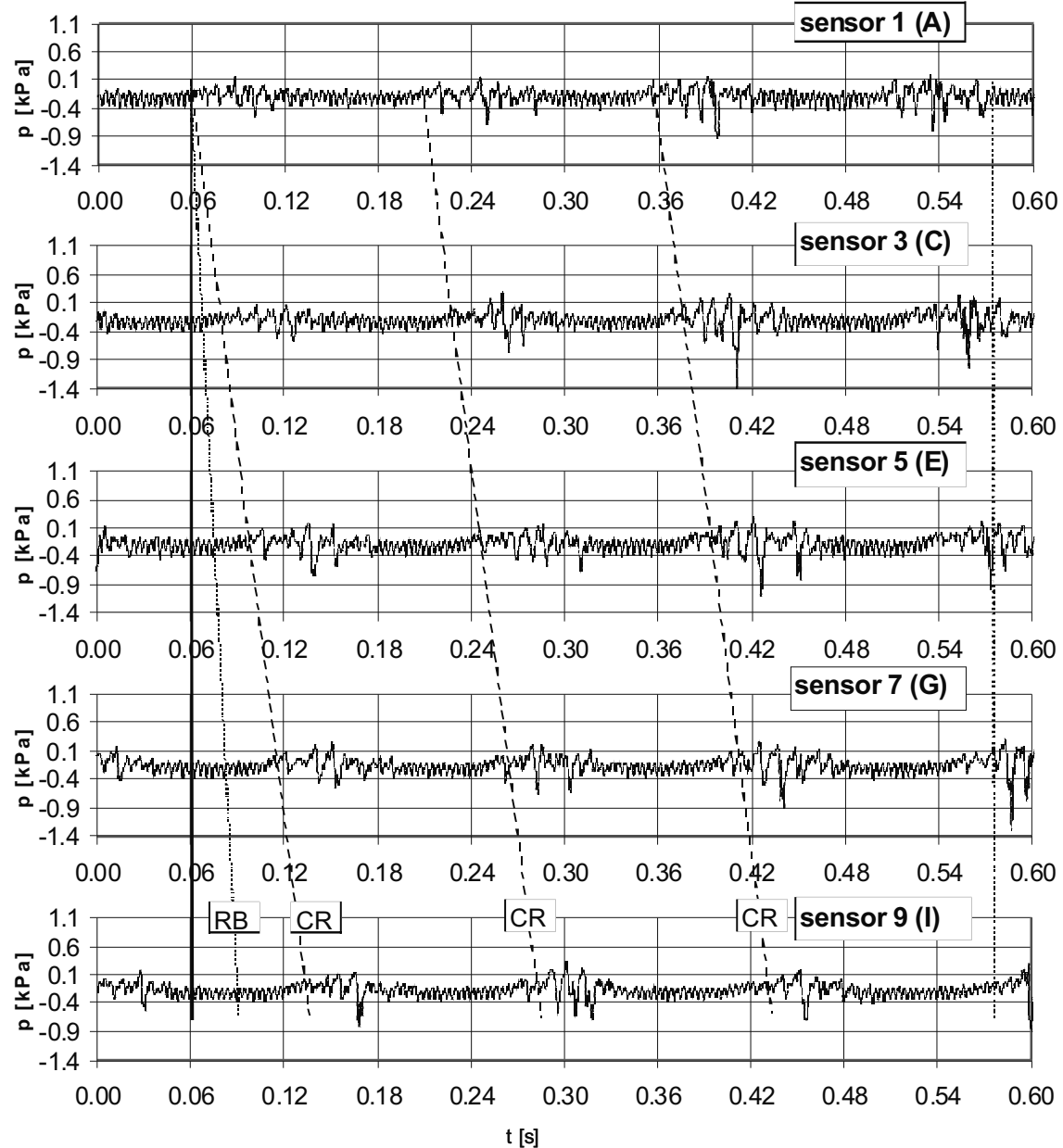

Fig. 5. Pressure variation over circumference of the rotor tip at operating point of $\phi=0.314$ 

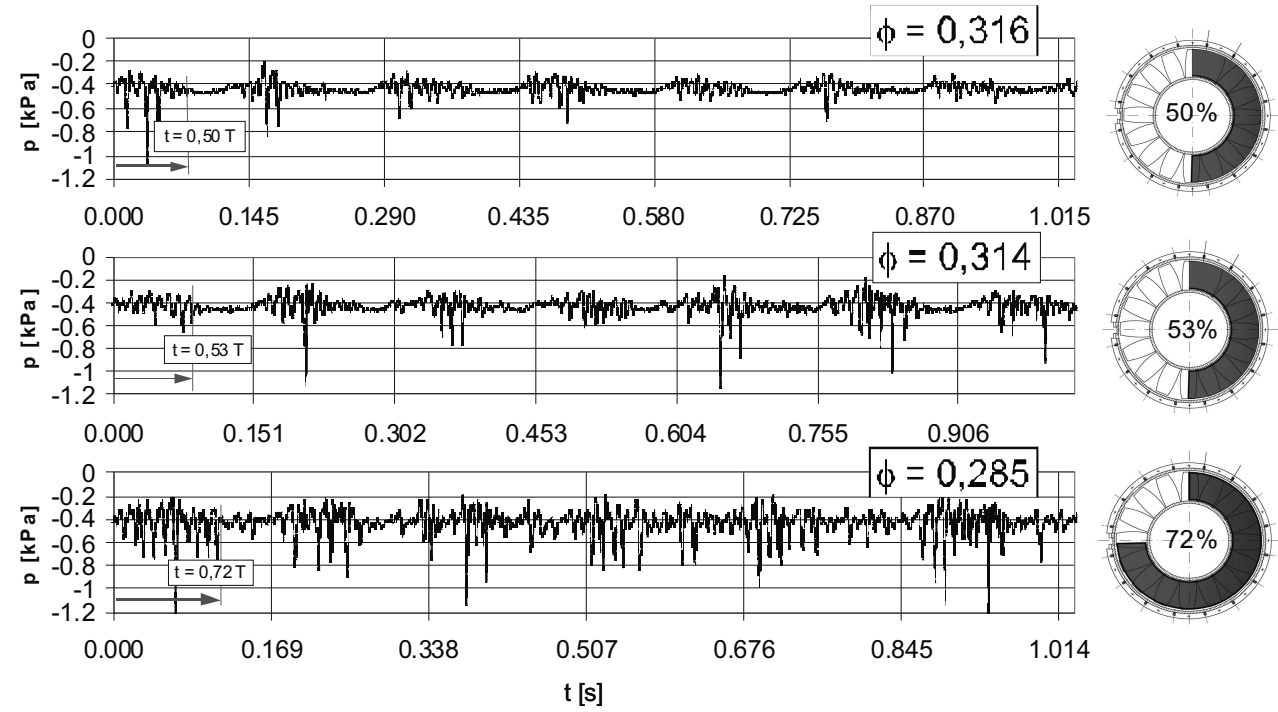

Fig. 6. Extent of the stall cell in circumference of the rotor at different points of operation

\section{The influence of operating point on circumferential extent of stall cell}

The number of rotor blade-to-blade channels disturbed by the rotating stall at different points of operation is not the main subject of most papers. To examine the influence of the point of operation on the spread of the stall cell in circumferential direction, in Figure 6 we show instantaneous pressure fluctuations upstream of the rotor at different points of operation during a steady process of rotating stall. We can see that, at the flow rate of $\phi=0.316$, the number of rotor blade passages disturbed by the stall cell is equal to $50 \%$. As the flow decreases to the value of $\phi=0.285$, the disturbed region increases and occupies about $72 \%$ of the rotor-blade passages. This suggests that, when the flow-rate coefficient decreases from 0.316 to 0.285 , the number of overloading blades with increased incidence and separated flow increases continuously.

\subsubsection{The Fast Fourier Transform}

The model of stability of incompressible compression system predicts rotating sinusoidal pressure perturbation in compressor at flow coefficients near the peak pressure rise. This prediction motivates decomposition of the discrete circumferential sensor data into harmonic components at each time sample (Fig. 7). To establish the existence and behavior of compression system modes the Fast Fourier decomposition has typically been used. 


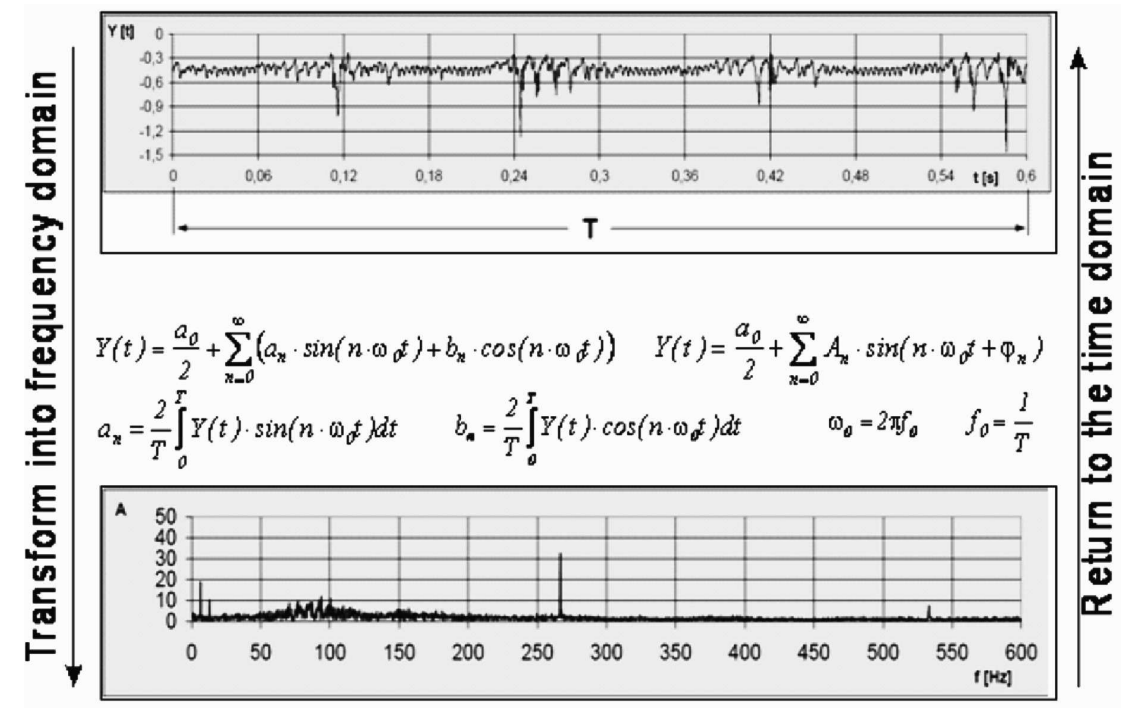

Fig. 7. Fast Fourier Transform(FFT) of the pressure signals

\section{Investigation of pressure fluctuations upstream of the rotor blades}

Figure 8 shows an example of pressure signals and pressure amplitude spectra appearing during stabilized rotating stall [17] at measuring point "0". The rotating instability is most clearly observed at axial measuring station "0" in Fig. 8. Visual inspection of stall behavior traces measured by the sensor (Fig. 8a) can provide meaningful information about rotating stall frequency. Frequency characteristics of the signals are shown in Figure $8 \mathrm{~b}$. Three types of pressure oscillations can be observed in this figure: low frequency pressure oscillations, LLSD (Fig. 8d), of frequency that is lower than the rotor speed frequency $(16.66 \mathrm{~Hz})$, ordinary rotating stall frequency $(6.6 \mathrm{~Hz})$, high frequency pressure oscillations with frequency equal to blade passing frequency, BPF, $(266.7 \mathrm{~Hz})($ Fig. 8a) and those with high-frequency oscillations, in the range between rotor speed and BPF, (SLSD) in the stall cells $(\sim 100 \mathrm{~Hz})$ after the blade passing frequency had been removed (Fig. 8c). All three kinds of oscillating processes can exist simultaneously.

\section{Investigation of pressure fluctuations along the blade passage}

Figure 9a shows a typical pressure fluctuation of the investigated compressor stage measured by pressure transducers at three axial locations along the curve corresponding to the camber of the rotor blades, within the unsteady flow region $(\phi=0.314)$. The pressure signals of these sensors are recorded simultaneously during the established rotating stall process. The high frequency of pressure oscillations during rotating stall is smaller than that of rotor ro- 

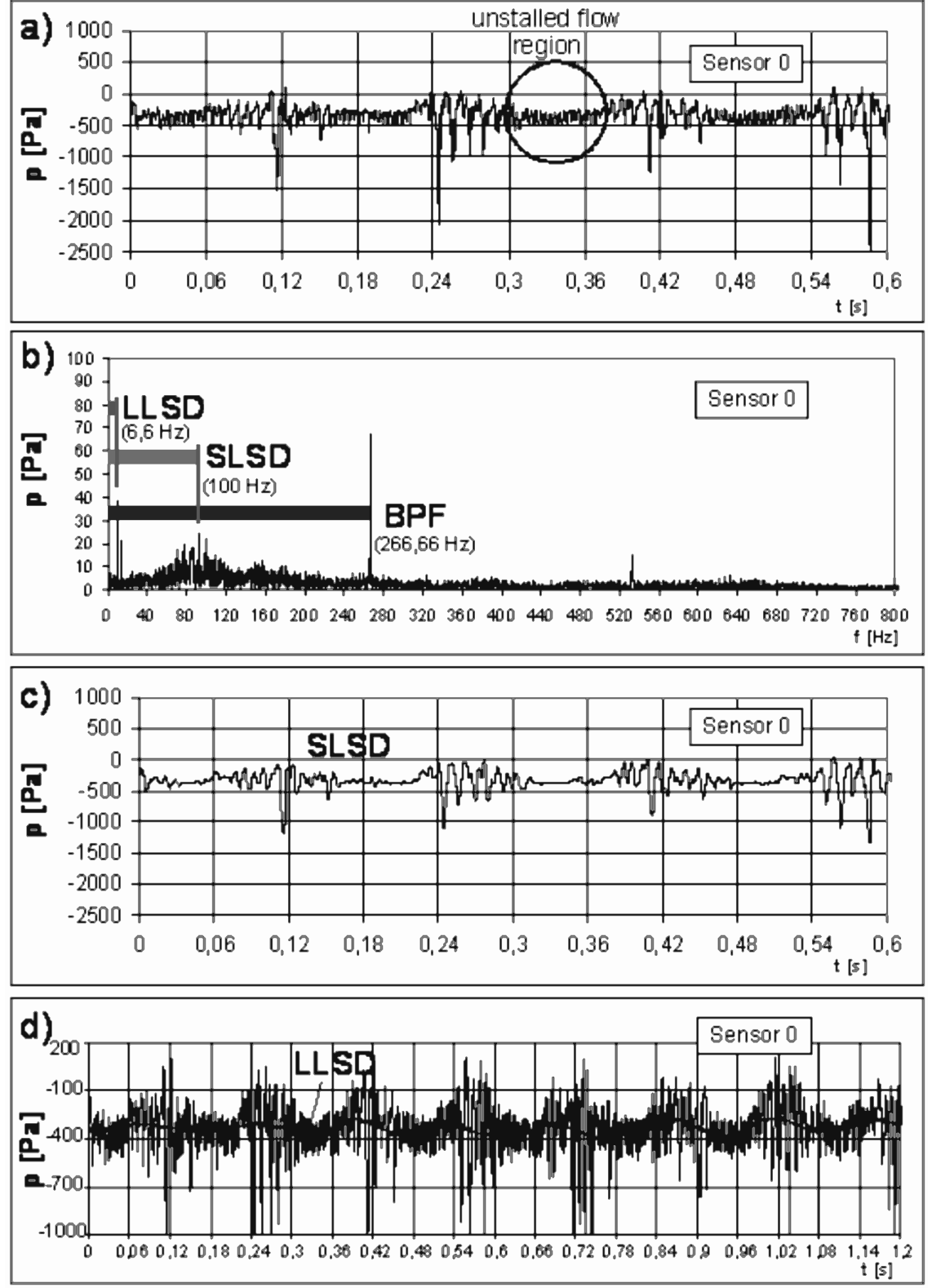

Fig. 8. Pressure variation on the outer casing wall during an established stall process, measured by the " 0 " sensor at $\phi=0.314$ (a), frequency characteristics of signals (b), Blade Pressure Frequency

Filtered-out, Short Length-Scale Disturbances (c), and Long Length-Scale Disturbances (d)

tation and significantly smaller than that of the blade passing frequency. The rotating instability is most clearly observed at axial measuring station "4" in Fig. 9a. As the flow passes to the next measuring stations $(10,16)$, the 
amplitudes of SLSD pressure fluctuations decrease continuously, however, the amplitudes of LLSD pressure fluctuations decrease from inlet sensor "4" to sensor "10" at the middle of the rotor blade passage and then increase to the downstream flow region (sensor 16)(Fig. 9b,c). These observations confirm the significant role of the inflow region of the rotor blade channel in the analysis of the events of the rotating stall in the tested compressor stage. It can be seen that there is a high fluctuation content in the entry plane of the rotor. In particular, maximal fluctuation amplitude can be found just ahead of the blade leading edge.

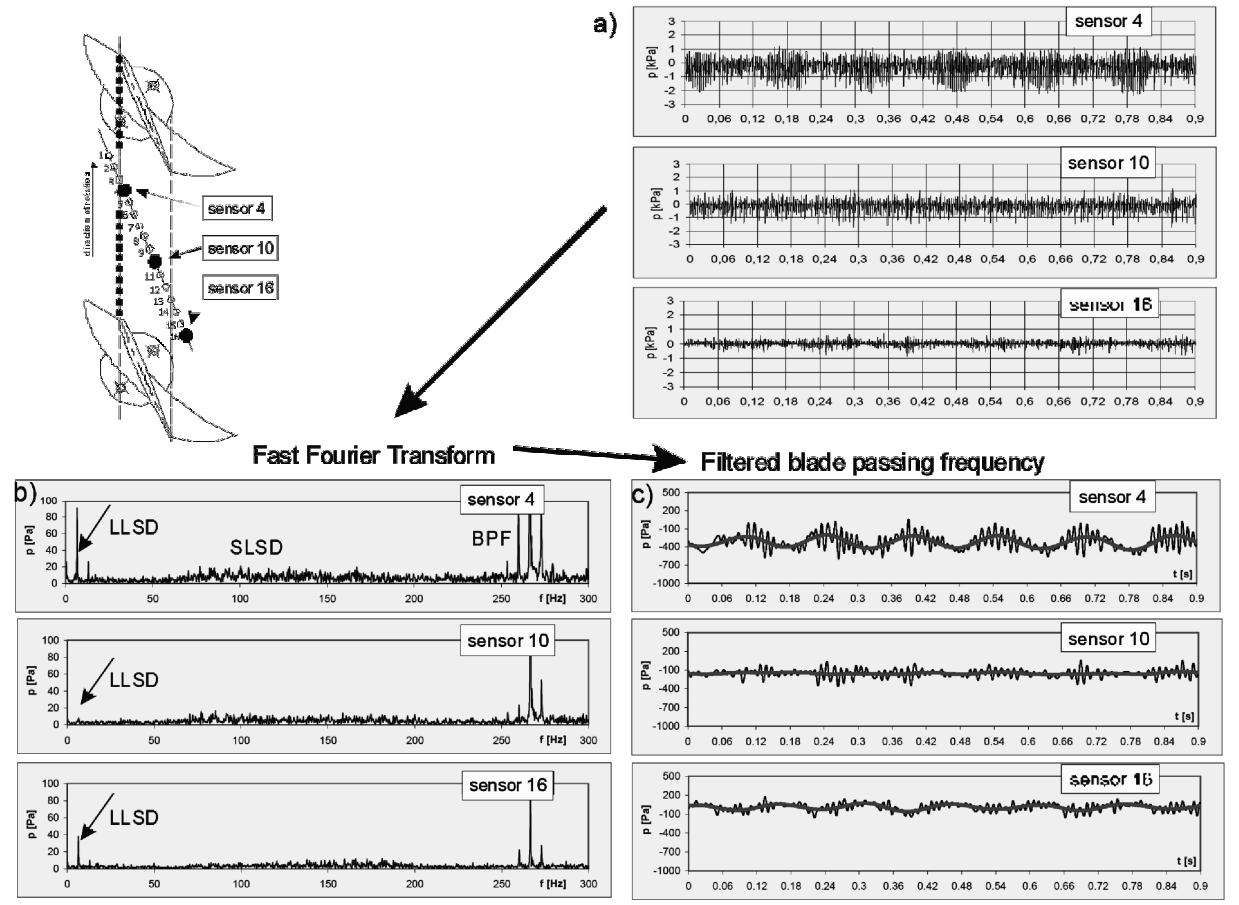

Fig. 9. Time history of wall pressure signals at three axial locations, at $\phi=0.314$, measured by the sensors (a), pressure amplitude spectra (b), wall pressure signals with filtered blade passing frequency (c)

\subsubsection{Wavelet Analysis}

In order to distinguish between the behavior of SLSD and LLSD, the low pass filtered traces were then analyzed by wavelet transforms. The behavior of short length-scale disturbances and long length-scale disturbances was examined by simultaneous measurements with sixteen pressure transducers mounted on the casing wall 1.3 axial chord of the profile blade ahead of the rotor leading edge at intervals of $22.5 \mathrm{deg}$ in the circumferential direction, 
with sixteen pressure transducers mounted on the casing wall in the axial direction, and with the use of the disc static pressure probe for inflow measurements along the rotor blade span. The component at blade passing frequency was removed by means of a low-pass filter, so that stall inception could be detected clearly. Fourier analysis of unsteady data provides information of the data, but lacks any temporal information. Wavelet analysis overcomes this shortcoming by the introduction of a non-sinusoidal basis function. Wavelet bases are constructed by stretching a single function, referred to as the mother wavelet, in the time domain. The wavelet transformations of a pressure signal $\mathrm{Y}(\mathrm{t})$ are defined by

$$
C(a, b)=\frac{1}{\sqrt{a}} \int_{t_{1}}^{t_{2}} Y(t) \cdot \psi(a, b, t) d t
$$

Where $\mathrm{Y}(\mathrm{t})$ is the tested pressure signal, $\psi(\mathrm{t})$ is the mother wavelet, " $\mathrm{a}$ " is the scaling parameter, " $\mathrm{b}$ " implies translation, and $\mathrm{T}=(\mathrm{t}-\mathrm{b}) / \mathrm{a}$ (Fig. 10). When an appropriate function is chosen, such as $\psi(\mathrm{t})$, a large value of $\mathrm{C}(\mathrm{a}, \mathrm{b})$ implies that the disturbance with scale "a" exists locally around "b". In our analysis, we have used the Morlet wavelet expressed as

$$
\psi(t)=e^{\frac{-t^{2}}{2}} \cdot \cos (5 t)
$$

Wavelet analysis is very attractive for data analysis, modeling, and active control of stall and surge in compressors. Figure 11 shows an example of the wavelet transforms of the rotor static pressure signal, in the stalling transient process for sensor number " 0 ", using a Morlet wavelet based on Eqs. (1) and (2). The presentation of the magnitude of the wavelet transform as a contour of the variables scale " $a$ " and time " $t$ " is commonly referred [1] to as a wavelet spectrogram. A rotating stall induced in a compressor stage by throttling the exit flow, to which equation (1) is applied, is shown in figure (11a). This event was sensed by a wall static pressure probe located upstream of the rotor. Three distinct phases of the rotating stall regime can be identified, as indicated in the picture. The these phases are: pre-stall, stall inception, and developed stall. Figure $11 \mathrm{~b}$ shows the contour maps of $\mathrm{C}(\mathrm{a}, \mathrm{b})$ calculated with the mother wavelets of Eqs. (2).

These plots contain a large amount of useful information about the features of the stall inception trace. The upper and the lower frame of figure $11 \mathrm{~b}$ are the contour maps of C $(\mathrm{a}, \mathrm{b})$ for LLSD and SLSD disturbances. The abscissa is $\phi$ and $\mathrm{t}$, and the ordinate is $\mathrm{a}=\mathrm{f}_{C} /\left(\mathrm{f}_{b f} \Delta \mathrm{t}\right)$, where $\Delta \mathrm{t}=0.118 \mathrm{~ms}$ is double time of the pressure sampling, $\mathrm{f}_{C}=0.76488$ is the constant, and 


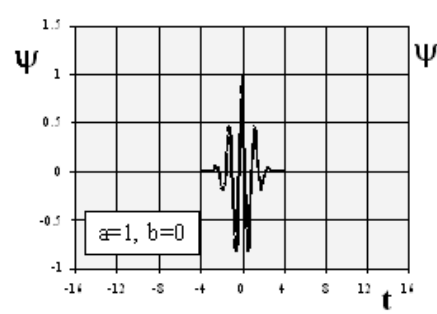

$C(a, b)=\frac{1}{\sqrt{a}} \int_{t_{1}}^{2} Y(t) \cdot \psi(a, b, t) d t$

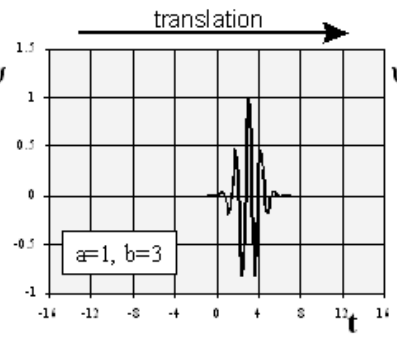

$\psi(a, b, t)=\psi\left(\frac{t-b}{a}\right)$

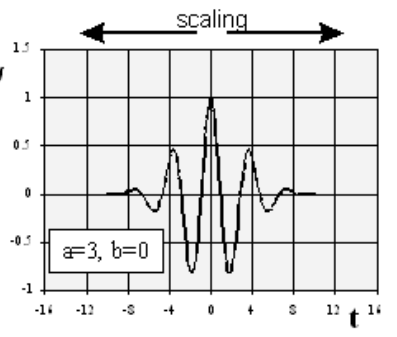

Morlet wajuelet

$\Psi(t)=e^{\frac{\tau^{2}}{2}} \cdot \cos (5 t)$

Fig. 10. Wavelet Transform Method

a)

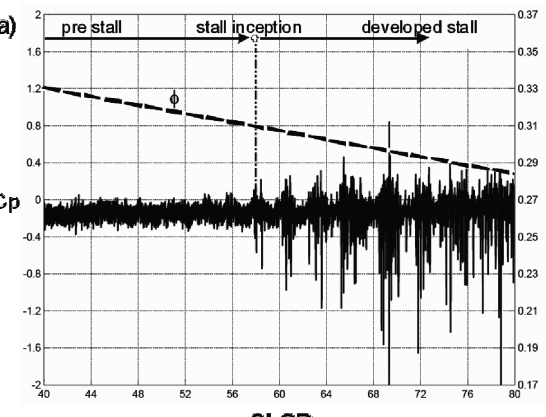

SLSD

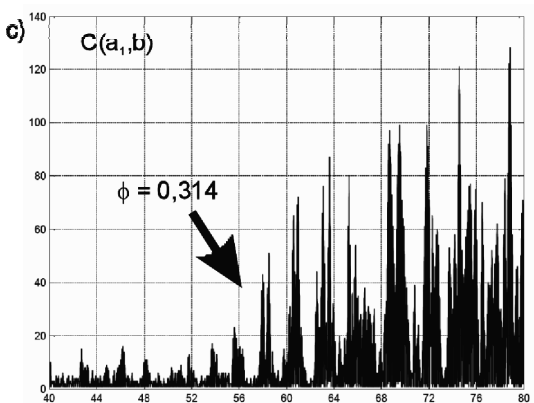

LLSD stall inception
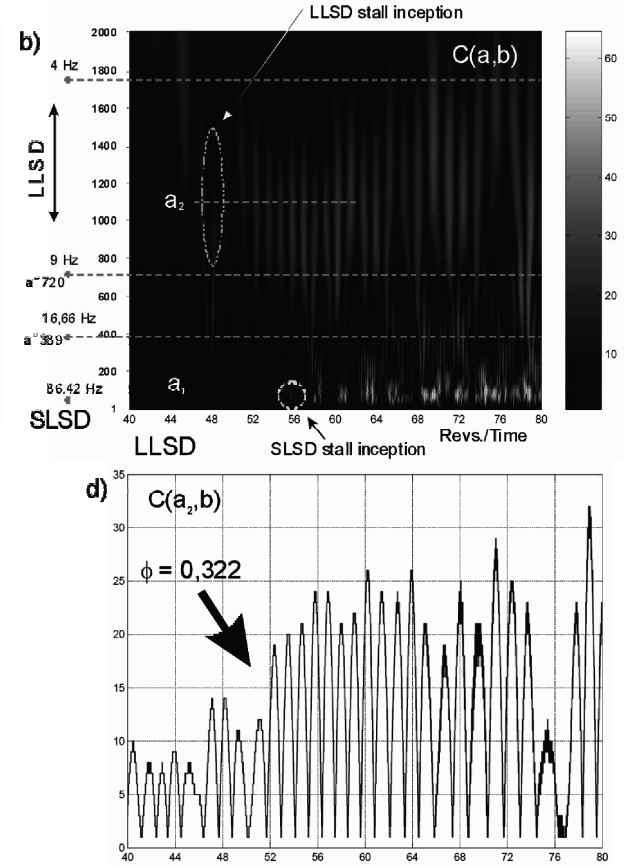

Fig. 11. Variation of wavelet transforms of static pressure signals of the casing rotor, near the rotor leading edge, in the transient stalling process: (a) time course of the pressure signals examined by visual inception, (b) Morlet wavelet spectrogram for specified scales of SLSD and LLSD, (c) variation of wavelet transforms with flow rate for scale of SLSD, and (d) variation of wavelet transforms with flow rate for scale of LLSD

$\mathrm{f}_{b f}=\mathrm{f}_{C} /(\mathrm{a} \cdot \Delta \mathrm{t})=6.482 \mathrm{kHz}$ is the frequency of the used basic wavelet. It is found that a spiky SLSD occurring on the lower part of figure $11 \mathrm{~b}$ reveals a high value of frequency near $86.42 \mathrm{~Hz}$, which corresponds to $\mathrm{a}=75 \mathrm{1} / \mathrm{s}$. The upper and middle part of the contour maps shows the maximum values of $\mathrm{C}(\mathrm{a}, \mathrm{b})$ located at $\mathrm{a}=(800-733) 1 / \mathrm{s}$ to which corresponds an LLSD of fre- 
quency $\mathrm{f}=4-9 \mathrm{~Hz}$. These LLSD frequencies are 1.85-4.16 times lower then the rotor frequency depending on the flow rate. In particular, a wavelet-based processing scheme for inlet pressures can detect of rotating stall precursors and provide reliable feedback for active control of stall and surge. Figure $11 \mathrm{~b}$ also shows that wavelet analysis is an excellent means of detecting frequency rotating stall in a time trace. Figures $11 \mathrm{c}$ and $11 \mathrm{~d}$ present the variation of wavelet transforms with flow rate for SSLD and LLSD scale in the transient scaling process. As a result, two types of stall inception can be observed in figure 11. One is a short wavelength stall inception (11c), which occurs at $\phi=0.314$, in which a short length-scale disturbance (SLSD) grows in size rapidly under a condition of high rotor incidence angles. Another is a long wavelength stall inception, which occurs at $\phi=0.322$, in which a long lengthscale disturbances (Fig.11d) grow in amplitude gradually under an unstable condition of the whole compression system [5]. The conclusion to be drawn from these tests is that these wavelets transforms make it possible to distinguish between the behavior of LLSD and SLSD. The second conclusion is that, in the case of pressure measurements on the casing near the rotor leading edge, the LLSD develops prior to the formation of SLSD, and the stalling process is identified in two steps. In the first step, the stalling process is identified with long length-scale disturbances, which were appreciable prior near time 10 revolutions to formation of a spiky SLSD. In the second step, the short length-scale disturbance has grown along with the long length-scale disturbances, and the compressor fells into a deep stall.

Figure 12 shows the variation of the RMS value of the wavelet transform of pressure signal measured during the stall transient process on the casing wall along the rotor blade passage (a), along the circumferential direction (b) and along the blade span, at the rotor's leading edge (c). When an appropriate function is chosen as $\psi(\mathrm{T})$, the large value of $\mathrm{C}(\mathrm{a}, \mathrm{b})$ (equation (1)) implies that the disturbance with scale $a$ exists locally around $b$. Figure 12a shows the axial extent of short length scale pressure disturbances at different points of operation. It indicates that the rotating stall is initiated in this case by a short length scale disturbances already at flow rate $\phi=0.34$. As the airflow rate decreased, the axial extent of this disturbances and its magnitude increased significantly. These disturbances are located at the region of the highest aerodynamic load of the blades and shifted slightly toward to the leading edge as the flow rate decreases (dotted line on figure 12a). In the next figure, $12 \mathrm{~b}$, we can find the circumferential extent of LLSD in the rotating stall cell at a different flow rate. According to a generally accepted idea [1,17], (Fig. 6) the decrease of propagating speed is linked with the increase of cell size [1], and vice versa. This idea has been confirmed by this wavelet analysis. For instance, at the flow rate of $\phi=0.316$, the number of rotor blade passages 


$$
R M S_{C}=\sqrt{\frac{\sum_{i=1}^{N}\left(C\left(a_{1,2}, b\right)_{i}-\overline{C\left(a_{1,2}, b\right)}\right)^{2}}{N}}
$$
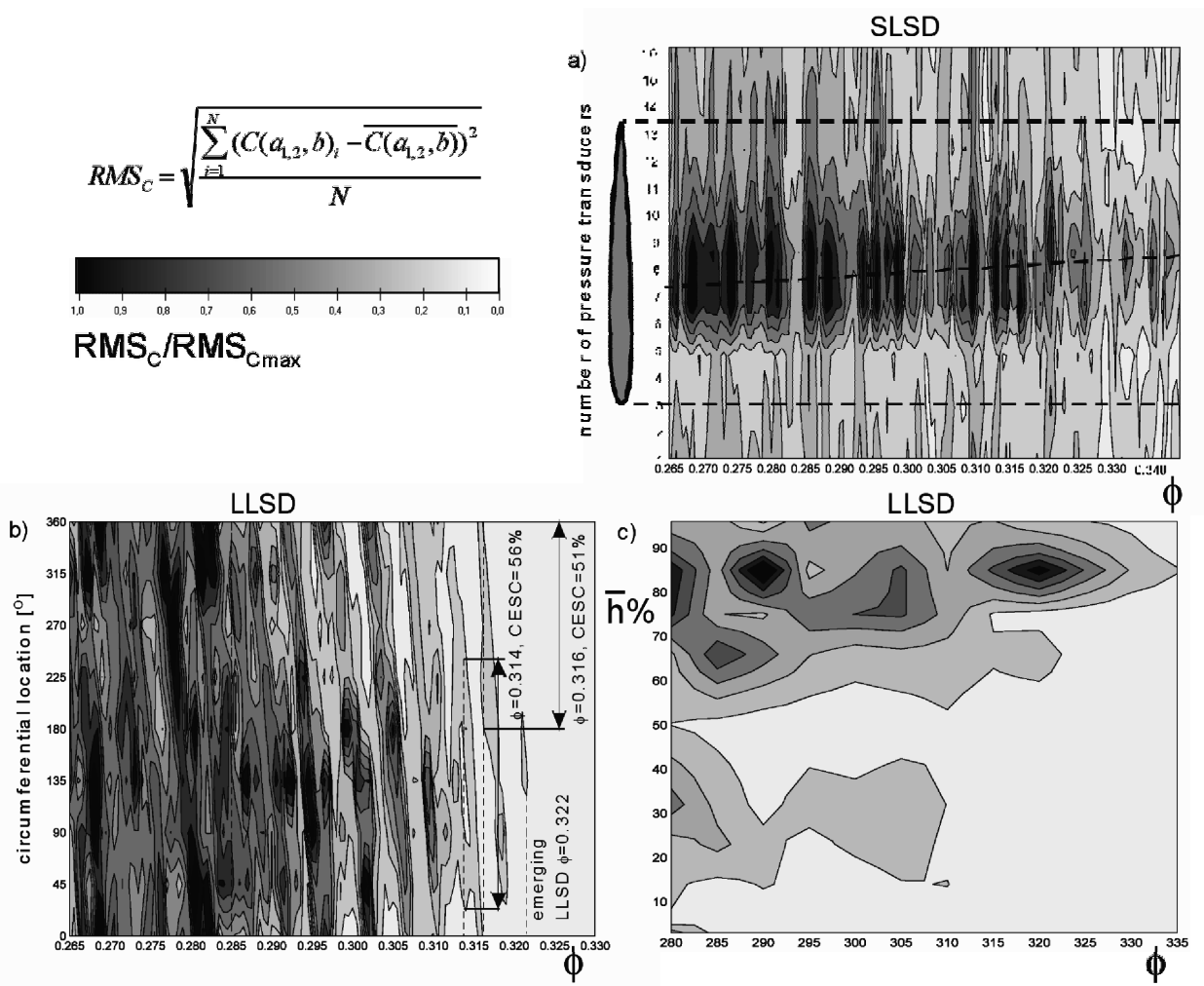

Fig. 12. RMS values of the wavelet functions during the stall transient process on the casing wall, SLSD along the rotor blade passage (a), LLSD, along the circumferential direction at the leading edge(b), and along the blade span, at the leading edge (c). CESC - circumferential extension of the stall cell

disturbed by the stall cell is about $51 \%$. As the flow decreases, the disturbed region also increases and occupies $56 \%$ of the rotor blade passages at the $\phi=0.314$ and than $100 \%$ of the rotor blade passages at the $\phi=0.285$. In this case, the incipient of the rotating stall is indicated by long length disturbances at a flow rate of $\phi=0.322$, which confirms the results shown in Figure $11 \mathrm{~d}$. This kind of analysis confirms previous results of visual inspection of the pressure fluctuation shown in our paper [17]. Figure 12c shows the spanwise distribution of the flow disturbances (LLSD) at the leading edge of the rotor blade during the stall transient process. It also confirms previous observation that the main disturbances are concentrated at the rotor inlet, close to the outer wall, where strong secondary flows exists. As the compressor stage is slowly throttled toward the stall, the region of these disturbances extends continuously from the outer wall to the middle and lower part of the rotor blade span. 


\section{Conclusions}

The process of rotating stall evolution was studied experimentally in a low-speed axial flow compressor stage. Measurements of wall pressure static fluctuations at the inlet of the rotor blade in the circumferential direction, along the rotor blade passage, and pressure static fluctuation distribution along the blade span at the inlet of the rotor were performed at a stable and unstable point of operation. The results can be summed up as follows:

- Behavior of short and long length-scale disturbances leading to a rotating stall can be examined closely by the wavelet analysis with the Morlet wavelet. The evolution of each disturbance can be examined simply by observing the variation of the wavelet transforms at a fixed scale corresponding to each of the disturbances.

- Behavior of the short and long length-scale disturbances is different depending on the point of localization of the pressure measurements. When the point of pressure signal measurement during the formation of the rotating stall was located on the outer wall at the inlet of the rotor, we observed that the LLSD developed prior to the SLSD inception. However, in the case when the point of pressure fluctuation is located on the outer wall on the middle of the rotor blade passage, the rotating stall is indicated earlier by a short length scale disturbances or spike.

- The analyzed results of FFT and the Wavelet Transform confirm that the two transforms provide substantially consistent results and facilitate understanding the characteristic of the stall cell.

Manuscript received by Editorial Board, October 18, 2010;

final version, December 10, 2010.

\section{REFERENCES}

[1] Cameron J. D.: Stall inception in a high-speed axial compressor, Ph. D. dissertation, Aerospace and Mechanical Engineering, Notre Dame Indiana, Jan. 2007, pp. 1-132.

[2] Day I.J.: Stall inception in axial flow compressors, ASME J. of Turbomachinery, 115, 1993, pp. 1-9.

[3] Inoue M., Kuroumaru M., Iwamoto T., Ando Y.: Detection of a rotating stall precursor in isolated axial flow compressor rotors, Journal of Turbomachinery, vol. 113, April 1991, pp. 281-289.

[4] Inoue M., Kuroumaru M., Ando Y.: Pressure fluctuation on casing wall of isolatd axial compressor rotors at low flow rate, J. of Turbomachinery, v.115, 1993, pp. 20-27.

[5] Inoue M., Kuroumaru M., Yoshida S., Furukawa M.: Short and length-scale disturbances leading to rotating stall in an axial compressor stage with different stator/rotor gaps, Trans. of the ASME, vol. 124, July 2002, pp. 376-384.

[6] Inoue M., Kuroumaru M., Yoshida S., Minami T., Yamada K., Furukawa M.: Effect of tip clearance on stall evolution process in a low-speed axial compressor stage, Proc. of ASME Turbo Expo 2004, Vienna, Austria. 
[7] Kim K.H., Shin Y.H., Kang C.S.: The measurements of unsteady flow field in an axial flow fan under stalled condition, Proc. of the International Gas Turbine Congress 2003 Tokyo, pp. $1-5$.

[8] Lepicovsky J., Braunscheidel E.P.: Measurement of flow pattern within a rotating stall cell in an axial compressor, NASA/TM-2006-214270, June 2006.

[9] Levy Y., Pismenny J.: The number and speed of stall cells during rotating stall, Proc. of ASME Turbo Expo 2003, June 16-19, 2003, Atlanta.

[10] Levy Y., Pismenny J., Schrapp H., Stark U., Saathoff H.: Pressure field at the tip of rotor blades before and during rotating stall, Proc. of the 7th European Conference on turbomachinery Fluid Dynamics and Thermodynamics, 5-9 March 2007, Athens, Greece.

[11] Maerz J., Hah C., Neise W.: An experimental and numerical investigation into the mechanisms of rotating instability, ASME J. of Turbomachinery, 2002, 124, pp. 367-375.

[12] Nishioka T., Kuroda S., Kozu T.: Influence of Rotor Stagger Rotating Stall inception in an Axial-flow Fan, Proc. of ASME Turbo Expo 2003, June 16-19, 2003, Atlanta.

[13] Nobuyuki T., Masahiro K., Yutaka O., Eisuke O., Tomofumi N., Yuki T.: Early stall warning technique for axial flow compressors, ASME Paper GT2004-53292.

[14] Witkowski A., Chmielniak T., Strozik M., Mirski M.: Facility for turbulence and unsteadiness measurements behind an axial compressor rotor blade by means periodic multisampling with triple split fiber probes, Proc. of the Second Biennial European Joint Conference on Engineering System Design and Analysis, London, July 4-7, 1994.

[15] Witkowski A., Majkut M.: Experimental investigation if inlet guide vane-rotor interaction in a low speed axial flow compressor stage, The Archives of Mechanical Engineering, Number $1,2006$.

[16] Witkowski A., Strozik M., Majkut M., Żukowski J.: Comprehensive Computational and Experimenal Methods of Investigations of the Unsteady Flow in an Axial Flow Low Speed Compressor Stage, 1-th edn. The Silesian University of Technology, 2007, pp. 1-212.

[17] Witkowski A., Ziach M., Majkut M., Strozik M.: Experimetal Investigations of the Flow Phenomena in the Rotor Blades of the Axial Flow Low Speed Compressor Stage at the Unstable Part of the Overall Performance Characteristic, The Archives of Mechanical Engineering, Vol. LV, Number 4, 2008, pp. 313-330.

\section{Zastosowanie transformaty falkowej do analizy sygnałów ciśnienia w obszarze pojawienia się wirującego oderwania w osiowym niskoobrotowym stopniu sprężającym}

$$
\text { Streszczenie }
$$

W pracy przedstawiono wyniki badań mających na celu wyjaśnienie zjawisk przepływowych towarzyszących pojawieniu się wirującego oderwania w osiowym niskoobrotowym stopniu sprężającym. Zjawiska niestacjonarne w stopniu sprężającym były badane poprzez próbkowanie pola ciśnień wysokoczęstotliwościowymi przetwornikami ciśnienia, zamontowanymi w osłonie zewnętrznej koła wirnikowego, w kierunku obwodowym na wlocie i w osi kanału międzyłopatkowego, oraz talerzykową sondą ciśnienia statycznego, wzdłuż wysokości łopatek wirnika. Badania te mają na celu rozpoznanie zjawisk przepływowych sygnalizujących pojawienie się wirującego oderwania i następnie pompowania oraz znalezienie sposobów umożliwiających przeciwdziałanie tym zjawiskom i ewentualne rozszerzenie roboczej charakterystyki pracy stopnia sprężającego. Do analizy zjawisk niestacjonarnych zastosowano trzy metody: metodę bezpośredniej analizy zarejestrowanych doświadczalnie pulsacji ciśnienia, metodę transformaty Fouriera oraz metodę transformaty falkowej, która umożliwia analizę sygnałów niestacjonarnych również w domenie czasowoczęstotliwościowej. Porównano wyniki analizy przeprowadzonej tymi trzema metodami i określono ich przydatność i ograniczenia. 